\title{
Characteristics of ozone and its precursors in Northern China: A comparative study of three sites
}

\author{
Yonghong Wang a,b , Bo Hu ${ }^{\mathrm{b}}$, Guiqian Tang ${ }^{\mathrm{b}}$, Dongsheng Ji ${ }^{\mathrm{b}}$, Hongxing Zhang ${ }^{\mathrm{d}}$, Jianhui Bai ${ }^{\mathrm{c}}$, \\ Xiaoke Wang ${ }^{\mathrm{b}}$, Yuesi Wang ${ }^{\mathrm{a}, \mathrm{b}, *}$ \\ ${ }^{a}$ Key Laboratory for Semi-Arid Climate Change of the Ministry of Education, College of Atmospheric Science, Lanzhou University, Lanzhou 730000, China \\ b State Key Laboratory of Atmospheric Boundary Layer Physics and Atmospheric Chemistry, Institute of Atmospheric Physics, Chinese Academy of Sciences, \\ Beijing 100029, China \\ c LAGEO, Institute of Atmospheric Physics, Chinese Academy of Sciences, Beijing 100029, China \\ d Research Center for Eco-Environmental Sciences, Chinese Academy of Sciences, Beijing 100085, China
}

\section{A R T I C L E I N F O}

\section{Article history:}

Received 20 November 2012

Received in revised form 19 April 2013

Accepted 21 April 2013

\section{Keywords:}

Ozone

Nitrogen oxide

Carbon monoxide

Urban

Rural

Background

\begin{abstract}
A B S T R A C T
Regional composite pollution and variation of atmospheric oxidizing ability are significant problems in Beijing and its surrounding areas. In particular, a southwest-northeast prevailing wind makes nonlinear variation of ozone and its precursors complex. In this study, simultaneous measurements of surface ozone $\left(\mathrm{O}_{3}\right)$, nitric oxide $(\mathrm{NO})$, nitrogen dioxide $\left(\mathrm{NO}_{2}\right)$, nitrogen oxide $\left(\mathrm{NO}_{\mathrm{x}}\right)$ and carbon monoxide (CO) were carried out from August 2009 to June 2010 to investigate ozone level and precursor concentrations in Northern China. Gucheng (GC), Longtanhu (LTH) and Xinglong $(\mathrm{XL})$ were selected to represent rural area, urban area and background area in North China Plain, respectively. The results showed that there were two peaks for primary pollutants $\left(\mathrm{NO}_{\mathrm{x}}\right.$ and $\left.\mathrm{CO}\right)$ at urban and rural areas, and the highest values appeared nearly on rush hours. There was a single peak for $\mathrm{O}_{3}$ and $\mathrm{O}_{\mathrm{x}}$ with peak values appearing at afternoon. The primary pollutants at urban and rural areas were higher than those in background region. However, the concentration of secondary pollutant $\mathrm{O}_{3}$ at downwind background areas was much higher than other sites due to transportation. Diurnal variations of pollutants indicated that $\mathrm{O}_{3}$ and $\mathrm{O}_{\mathrm{x}}$ had peak values at afternoon, while other primary pollutants showed two peak values nearly on rush hours. Furthermore, high concentrations of $\mathrm{O}_{3}$ and $\mathrm{O}_{\mathrm{x}}$ at background site $\mathrm{XL}$ also implied a robust atmospheric oxidizing ability. A positive correlation was observed between $\mathrm{CO}$ and $\mathrm{O}_{3}$ at $\mathrm{XL}$ site, which implied that air masses to the site had a large loading of anthropogenic emission experiencing strong photochemical processing. The correlation between $\mathrm{CO}$ and $\mathrm{O}_{3}$ was negative at GC and LTH, which indicated that local emission of precursors had significant influence on the formation of ozone. There was a positive correlation between $\mathrm{NO}_{\mathrm{x}}$ and $\mathrm{O}_{\mathrm{x}}$ at $\mathrm{GC}$ and $\mathrm{XL}$, which implied that $\mathrm{NO}_{\mathrm{x}}$ contributed to the formation of ozone, while a negative correlation meant titration in urban site LTH neutralized the formation of ozone due to high level of NO.
\end{abstract}

(c) 2013 Elsevier B.V. All rights reserved.

\section{Introduction}

Surface ozone plays a crucial role in both stratosphere and troposphere as a secondary pollutant, which is produced by

\footnotetext{
* Corresponding author at: Key Laboratory for Semi-Arid Climate Change of the Ministry of Education, College of Atmospheric Science, Lanzhou University, Lanzhou 730000, China.

E-mail address: wys@dq.cern.ac.cn (Y. Wang).
}

the photochemical oxidation of carbon monoxide ( $\mathrm{CO}$ ) and non-methane volatile organic compounds (NMVOCs) in the presence of nitrogen oxides. In the stratosphere, it can absorb ultraviolet radiation (Mckenzie et al., 1999), which does harm to human beings and other creatures, also in the troposphere a suitable amount of ozone is beneficial for air purification because of its high reactivity. However, with the rapid growth of industrialization and urbanization, the pollution of surface ozone and $\mathrm{NO}_{\mathrm{x}}$ has been an intractable problem in the mega 
cities and population centers (Jacob et al., 1993; Wang et al., 2006; Shan et al., 2008, 2009, 2010; Chelani, 2009; Xin et al., 2010; Tang et al., 2012). Generally, the levels of photochemical oxidants can be reduced by controlling their precursors (i.e. $\mathrm{NO}_{\mathrm{x}}$ and $\mathrm{VOC}_{\mathrm{S}}$ ) (Seinfeld and Pandis, 2006). However, it should be noted that the levels of $\mathrm{O}_{3}$ and $\mathrm{NO}_{\mathrm{x}}$ are inextricable linked resulting from the chemical coupling of ozone and nitrogen oxides (Minoura, 1999). Thus, the response to the reduction of nitrogen oxide emissions is nonlinear and any resultant reduction of nitrogen dioxide is accompanied by an increase concentration of ozone (Mazzeo et al., 2005; Singla et al., 2011).

The North China Plain (NCP) region, one of the areas with the highest population density all over the world, has suffered from severe air pollution for decades. Many studies (Wang et al., 2006, 2010; Streets et al., 2007; Xu et al., 2011a, 2011b, 2011c; Lin et al., 2011; Tang et al., 2012) have been conducted on surface ozone in Beijing and its surrounding cities. Lin et al. (2008) found that ground ozone level and atmospheric oxidant $\mathrm{O}_{\mathrm{x}}\left(\mathrm{O}_{\mathrm{x}}=\mathrm{O}_{3}+\mathrm{NO}_{2}\right)$ in a rural site of NCP were $28.5+$ $13.8 \mathrm{ppb}$ and $47.1+8.5 \mathrm{ppb}$, respectively. Researches on Beijing area (Wang et al., 2006; Xu et al., 2011a, 2011b, 2011c; Tang et al., 2009, 2012) showed that surface ozone mixing rate varied significantly from place to place, exceeded the standard of National Environmental Quality in many observation periods.

Previous studies mainly focus on the variation of a single station, which can give us limited knowledge of the characteristics of surface ozone and atmospheric oxidation ability. In particular, air pollution in North China Plain has been a severe regional composite pollution (Xu et al., 2011a, 2011b, 2011c; Streets et al., 2007; Chan and Yao, 2008; Duan et al., 2008) of fine particle matters and gaseous pollutants due to the massive consumption of fossil fuel. Different kinds of topographical sites should be put together to investigate air pollution problems on a regional scale. However, there is only a few researches on regional scale pollution of surface ozone (Lin et al., 2008; Tang et al., 2012) compared with that in other places of China (Tu et al., 2007; Sun et al., 2010; Tang et al., 2012) and other population delta in European and American (Li et al., 2002; Chu et al., 2003; Grewe et al., 2012).

To achieve the promising goal of "Green Olympic Game" in the 29th Summer Olympic Games, Beijing government took many effective measures to reduce anthropogenic emissions cooperating with other local governments in the NCP. For instance, local governments in the NCP have managed to relocate old industrial facilities. Some 300000 heavily polluting vehicles (the so called yellow-label vehicles) were banned from driving in the Beijing Municipality, and other vehicles have been restricted rigorously based on the odd and even number rule. The road-traveling automobiles reduced about 1.95 million a day during the Olympic Games (Mao, 2008). As a result, the mean concentration of $\mathrm{O}_{3-8 \mathrm{~h} \text { max }}, \mathrm{O}_{\mathrm{x}}, \mathrm{NO}_{2}$ and $\mathrm{PM}_{2.5}$ was $114 \pm 29 \mu \mathrm{g} \mathrm{m}^{-3}, 95 \pm 17 \mu \mathrm{g} \mathrm{m}^{-3}, 23 \pm 4 \mu \mathrm{g} \mathrm{m}{ }^{-3}$ and $56 \pm 28 \mu \mathrm{g} \mathrm{m}^{-3}$ in the region during the Olympic Games, respectively, and fell by $20.2 \%, 18.9 \%, 13 \%$ and $43.7 \%$, respectively (Xin et al., 2010).

In this study, surface ozone level and atmospheric oxidation ability in urban area, rural area and background area of NCP were investigated via data sets from three selected sites. Comparative study of surface ozone was conducted through annual variation, daily variation, atmospheric oxidation ability and precursor concentration correlation with ozone formation, along with meteorological parameters in the observation period. We hope the study will benefit air pollution control in NCP.

\section{Methods and data}

\subsection{Site location and weather conditions}

Gucheng (GC) site $\left(39^{\circ} 15 \mathrm{~N} .115^{\circ} 73 \mathrm{E}, 15.2 \mathrm{~m}\right.$ asl), positioned in countryside of Baoding city, is in the central zone of BeijingTianjin-Baoding area as Fig. 1 shows. Taihang Mountains (south-west-to-northeast trend) is about $30 \mathrm{~km}$ away from the west of the site. The highway connecting Beijing and Shijiazhuang is about $7 \mathrm{~km}$ away from east of the site. In addition, the surrounding of the site is farms and village. The main crops are wheat in winter and spring whereas corn in summer and fall (Lin et al., 2009). Longtanhu (LTH) site $\left(39^{\circ} 87 \mathrm{~N} .116^{\circ} 43 \mathrm{E}, 44 \mathrm{~m}\right.$ asl) is located in Longtanhu park within the second Ring Road. The highway from Beijing to Tianjin and Beijing to Shenyang is in the south of the site. The surrounding of the site is covered with grasses and trees. Thus, the site in the central of Beijing can stand for pollution level in urban background area of NCP region. Xinglong (XL) site $\left(40^{\circ} 39 \mathrm{~N} .117^{\circ} 57 \mathrm{E}, 960 \mathrm{~m}\right.$ asl) is in the south of Yanshan Mountains, located in the National Astronomical Observation Base of Hebei province. Fig. 2 showed air mass backward trajectories at XL site during observation periods using HYSPLIT. The air mass from south contributes $45 \%$ (air mass 3 ), and the air masses from northwest contribute to 37\% (air mass 2 and air mass 4). Beijing is about $115 \mathrm{~km}$ from southwest in a straight line and industrial city Tangshan is about $100 \mathrm{~km}$ from southeast. The surrounding is covered with trees and bushes, and villagers in this arcadia live on fruit trees and are farmers. Thus, it is appropriate to carry out background observation of the atmospheric composition in NCP region.

The weather in NCP is typically influenced by monsoon circulation, which means that the meteorological factors have significant transition from season to season. The meteorological data is obtained from China Meteorological Data Sharing Service System (http://cdc.cma.gov.cn/home.do). The four seasons are established according to astronomy, which means that spring includes March, April and May; Summer includes June, July and August; fall includes September, October and November; and winter includes December, January and February. Fig. 3 showed a general weather condition of Beijing during the observation period, the precipitation mainly occurs in summer with lower pressure, while the humidity and temperature are lower in winter and higher in other seasons. The wind speed and wind direction of four seasons are presented in Fig. 4. The extreme high-wind speed corresponding with wind direction is mostly less than $4 \mathrm{~m} \mathrm{~s}^{-1}$, and the prevailing wind directions are NNE and SE, especially in summer and winter. The three sites, located on the route of southwest to northeast prevailing wind, are suitable places of studying surface ozone chemistry in NCP.

\subsection{Instruments and data sets}

Commercial trace gas instruments (Thermo Environmental Instruments Inc., USA i-Series) were utilized to continuously 


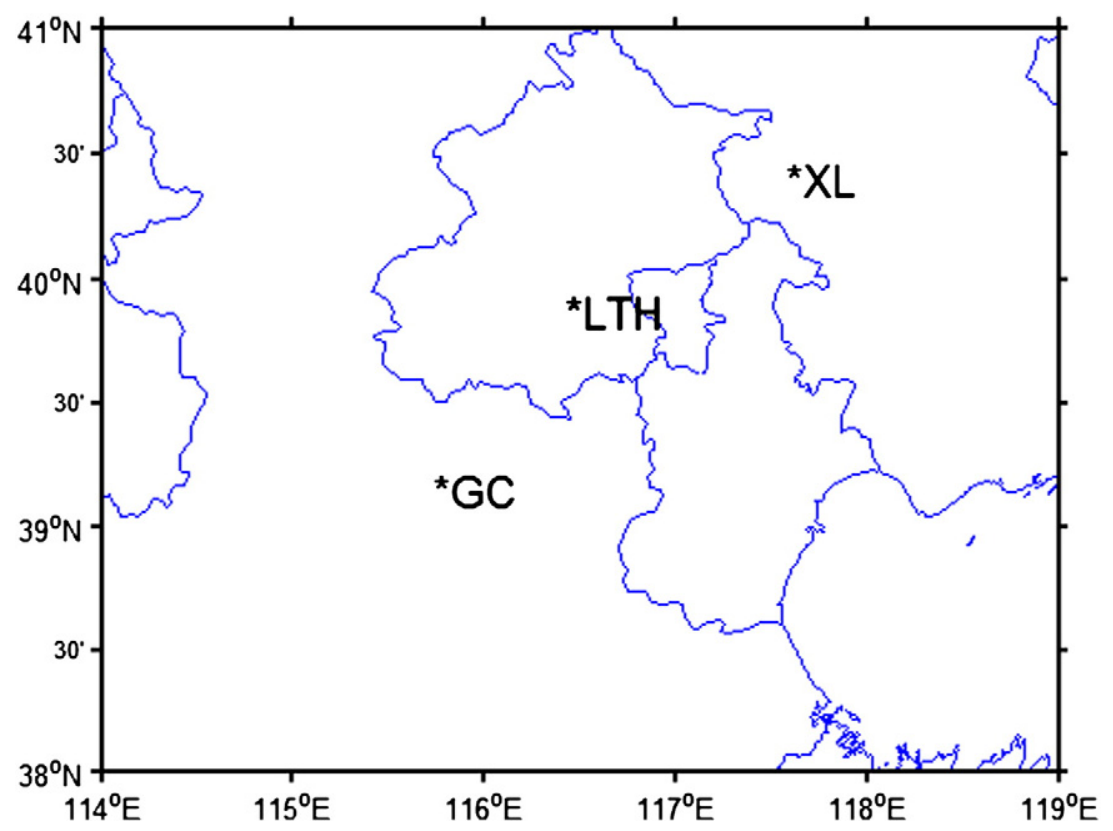

Fig. 1. Location of the three observation sites, blue line is province boundaries.

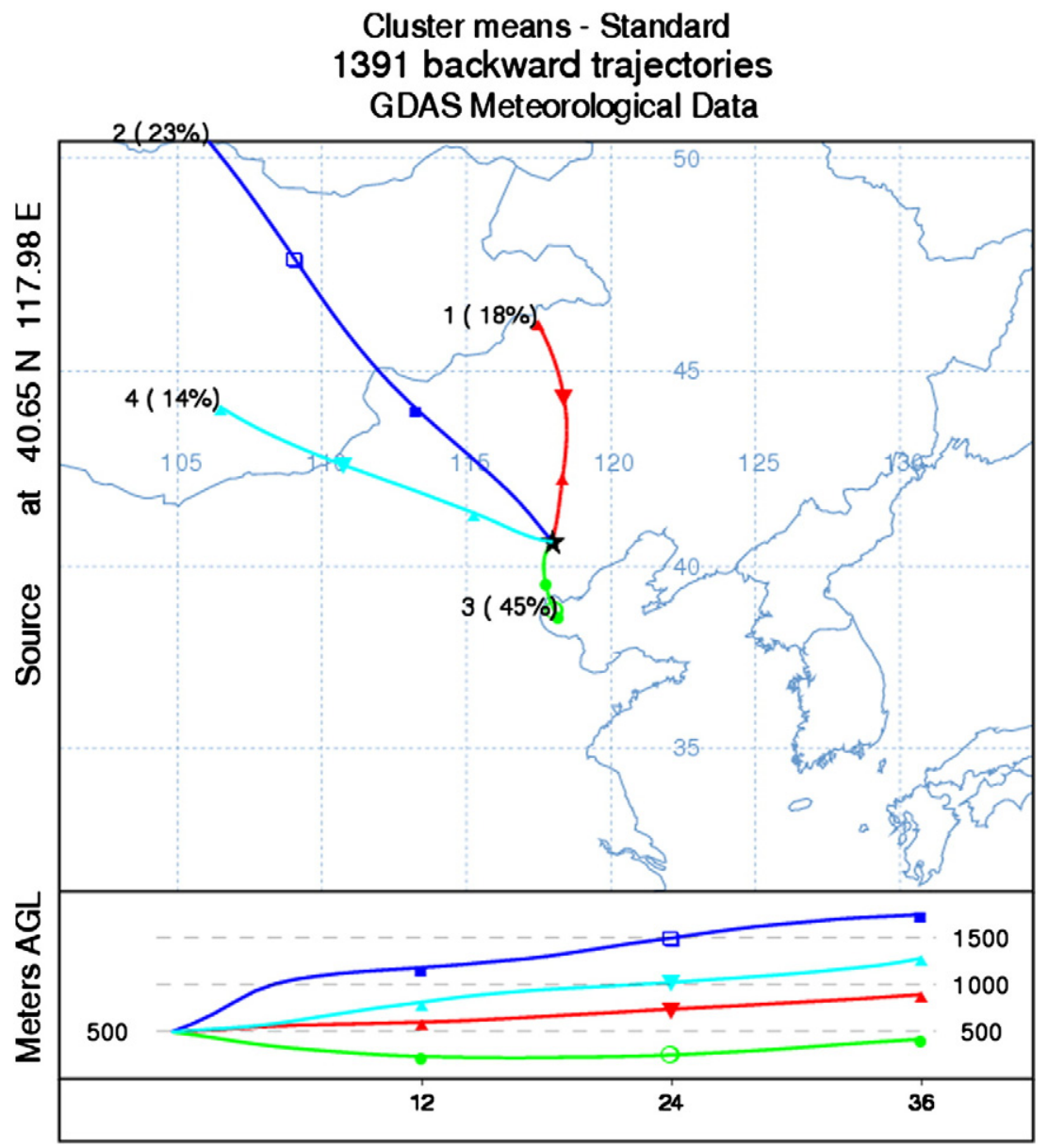

Fig. 2. Air mass backward trajectories using HYSPLIT at XL site during observation periods (http://ready.arl.noaa.gov/HYSPLIT.PHP). 

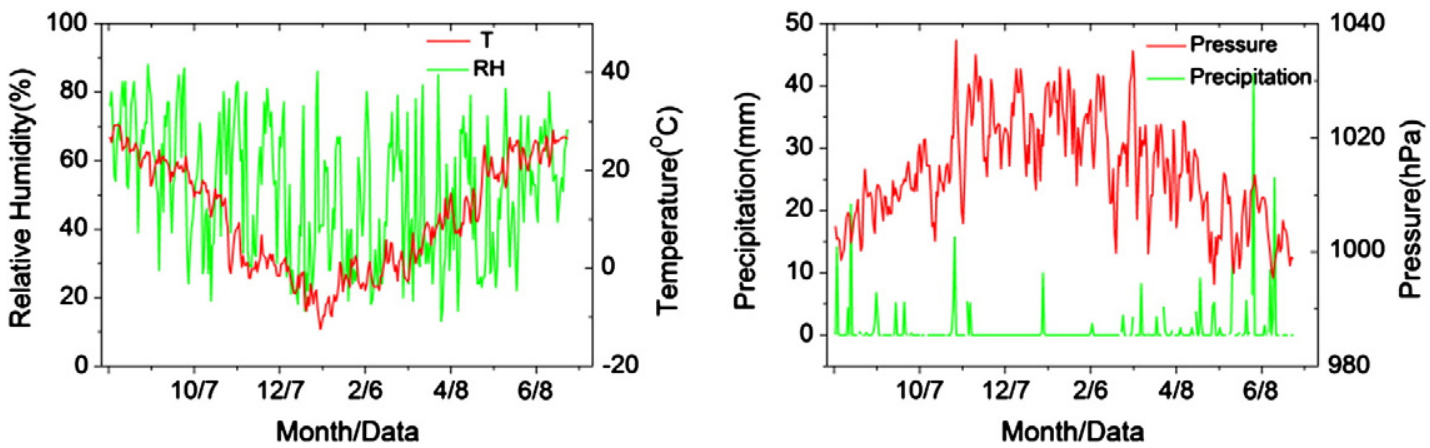

Fig. 3. Daily records of precipitation, pressure, relative humidity and temperature in the NCP of Beijing during the observation period.

measure concentrations of $\mathrm{O}_{3}(49 \mathrm{i}), \mathrm{CO}(48 \mathrm{i})$ and $\mathrm{NO} / \mathrm{NO}_{2} / \mathrm{NO}_{\mathrm{x}}$ (42i) at XL and LTH. The instruments used at GC were $\mathrm{O}_{3}(49 \mathrm{C})$, $\mathrm{CO}(48 \mathrm{C})$ and $\mathrm{NO} / \mathrm{NO}_{2} / \mathrm{NO}_{\mathrm{x}}(42 \mathrm{CTL})$. The detailed calibrations of those instruments at GC site have been introduced by Lin et al. (2009). The 49i ozone $\left(\mathrm{O}_{3}\right)$ analyzer operates on the principle that ozone molecules absorb UV light at a wavelength of $254 \mathrm{~nm}$. The degree to which the UV light is absorbed is directly related to the ozone concentration. The 48i carbon monoxide (CO) analyzer operates on the principle that carbon monoxide absorbs infrared radiation at a wavelength of $4.6 \mu \mathrm{m}$. The 42i nitrogen oxide $\left(\mathrm{NO}_{\mathrm{x}}\right)$ analyzer operates on the principle that nitric oxide (NO) and ozone $\left(\mathrm{O}_{3}\right)$ react to produce a characteristic luminescence with intensity linearly proportional to the NO concentration (www.thermoscientific. com). Multipoint calibrations of $\mathrm{O}_{3}$ analyzer were made using a zero air supplier (Model 111) and an $\mathrm{O}_{3}$ calibrator (TE 49C PS). The calibrations of $48 \mathrm{i}$ and $42 \mathrm{i}$ were conducted by a dynamic gas calibrator (Model 146) in cooperation with the zero air supplier (Model 111), and a standard reference gas mixture ( $\mathrm{NO} / \mathrm{CO}$ in $\mathrm{N}_{2}$ ) was used for multipoint calibration and regular zero/span checks. Besides, the gases of NO and CO were compared with NIST-traceable standards from Scott Specialty Gases of USA for traceability. The instrument would be replaced by another i-Series instrument from standby instruments if its components (gas flow meter, solenoid valve, pump, etc.) were broken. Consequentially, the replacement among instruments from site to site could minimize error caused by the instrument itself. Air inlets (Teflon) were placed on the housetops of the
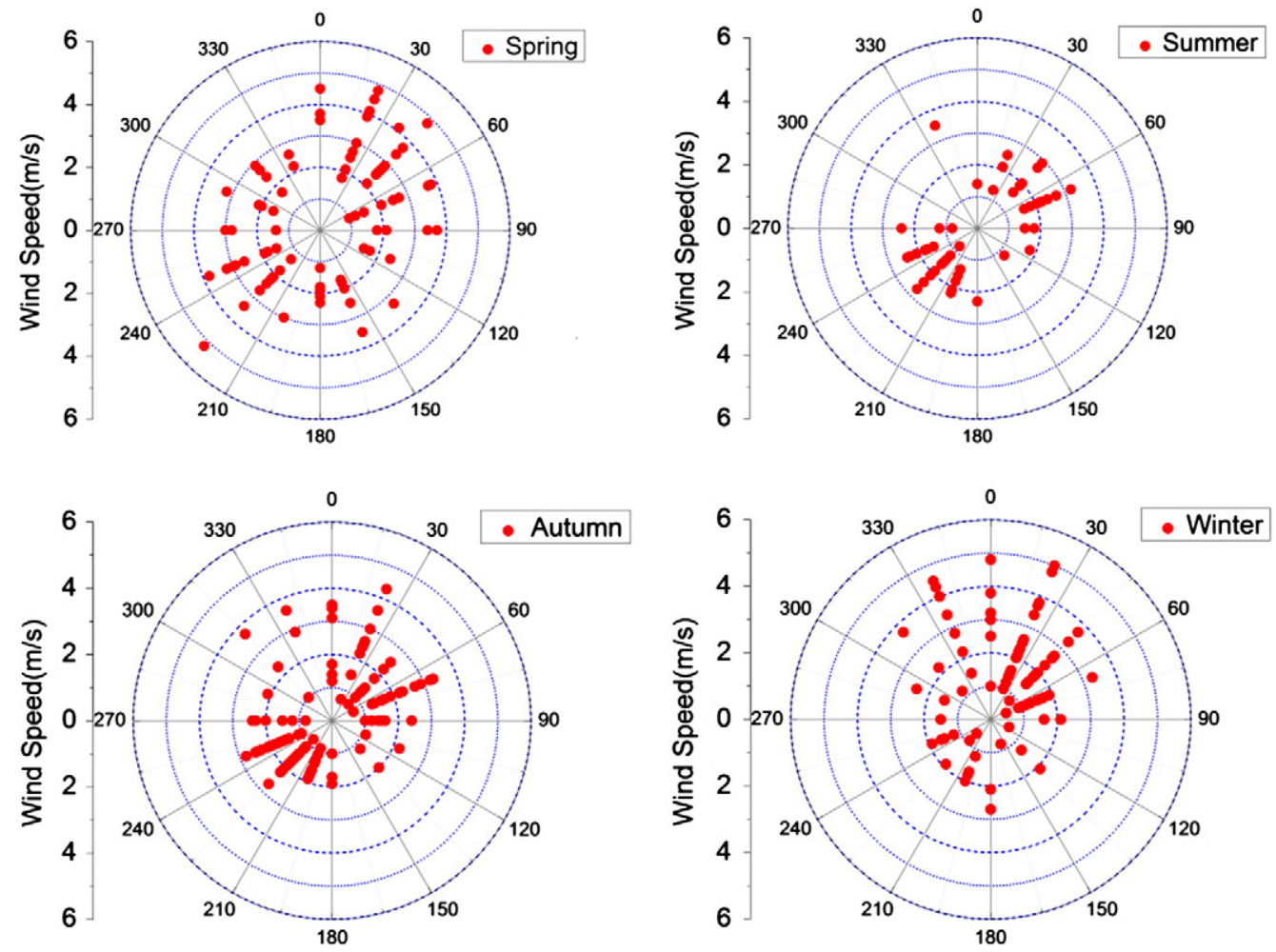

Fig. 4. Seasonal records of extreme high-wind speed corresponding with wind direction in the NCP of Beijing during observation period. 
three sites and shared by each instrument. Moreover, the laboratories where the instruments are were all provided with an air-conditioner, which could keep the air temperature around $25{ }^{\circ} \mathrm{C}$.

High resolution (5-minute averages) data sets from August 2009 to June 2010 were obtained and 1-hour average data were presented after strict quality control. No data were available on some days due to the malfunction of the instruments. In particular, no data were obtained in July 2010 due to laboratory reconstruction at XL. Thus, data in July at the other two sites were also not used in the study.

\section{Results and discussion}

\subsection{Hourly variation of the pollutants}

Fig. 5 showed that the concentrations of $\mathrm{O}_{3}, \mathrm{NO}_{\mathrm{X}}$ and $\mathrm{CO}$ have "saw-toothed" patterns, which meant the pollutant concentration could accumulate to high levels and then decreased to low levels. This was mainly due to the daily variation of boundary layer and the cycle of man-made emissions. In general, $\mathrm{O}_{3}$ level was high from August to June in XL but low in GC and $\mathrm{LTH}$, the concentration of $\mathrm{NO}_{\mathrm{x}}$ and $\mathrm{CO}$ was higher than that in $\mathrm{XL}$ and the variation patterns of $\mathrm{NO}_{\mathrm{x}}$ and $\mathrm{CO}$ were fairly synchronous, while that of $\mathrm{O}_{3}$ nearly reversed.

The annual average concentrations and standard deviations of $\mathrm{O}_{3}, \mathrm{NO}_{\mathrm{x}}, \mathrm{CO}$ and site information are presented in Table 1 . The concentrations of $\mathrm{O}_{3}, \mathrm{NO}_{\mathrm{x}}$ and $\mathrm{CO}$ in $\mathrm{GC}$ were $19.4 \pm 7.9 \mathrm{ppb}$, $46.4 \pm 15.1$ and $1340 \pm 593$, respectively. The concentrations of $\mathrm{O}_{3}$ and $\mathrm{CO}$ were lower than that (28.5 ppb and $1520 \mathrm{ppb}$ ) reported by Lin et al. (2009) at the site, while the concentration of $\mathrm{NO}_{\mathrm{x}}$ has significantly increased by $17 \mathrm{ppb}$ since the last report. The average $\mathrm{O}_{3}$ was slightly lower than that in the extensive studies of Beijing urban area in the last decade (Chan and Yao, 2008; Xu et al., 2011a, 2011b, 2011c), while the concentrations of $\mathrm{NO}_{\mathrm{x}}$ and $\mathrm{CO}$ varied from place to place. Background observations in north China are very lacking, and only continuous observation work was held in Shangdianzi (SDZ), which is a Global Atmosphere Watch (GAW) stations. The concentrations of $\mathrm{O}_{3}$ and $\mathrm{CO}$ at XL were lower than that (58.2 ppb, $910 \mathrm{ppb}$ ) reported at SDZ by Xu et al. (2011a, 2011b, 2011c). Broadly speaking, the variation of air pollutants in

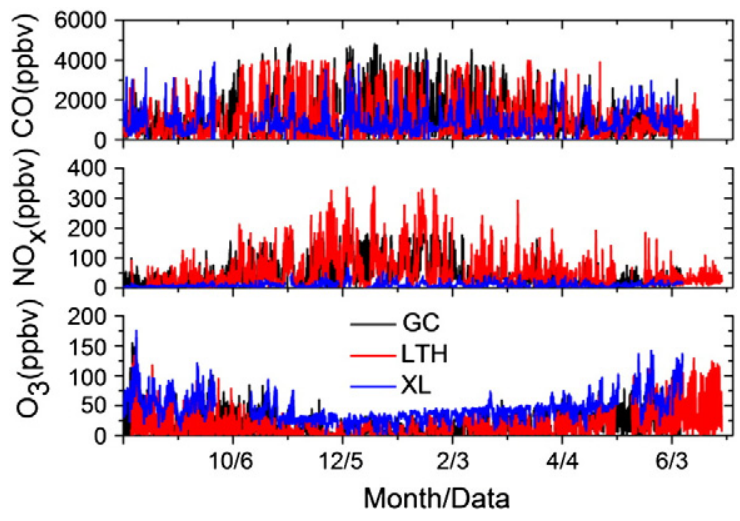

Fig. 5. Hourly concentrations of $\mathrm{O}_{3}, \mathrm{NO}_{\mathrm{x}}$ and $\mathrm{CO}$ at the three sites during the observation period.
Beijing and its surrounding areas was complicated, however, the comparison work is seldom been touched.

\subsection{Monthly variation}

The monthly variation of $\mathrm{O}_{3}, \mathrm{NO}_{\mathrm{x}}, \mathrm{NO}_{2}, \mathrm{NO}, \mathrm{O}_{\mathrm{x}}$ and $\mathrm{CO}$ for $\mathrm{GC}, \mathrm{LTH}$ and XL is shown in Fig. 6. The concentration of $\mathrm{O}_{3}$ had a higher value in summer but a lower value in winter at the three sites. As Fig. 6a showed, the maximum concentrations all appeared in June with values of $44.3 \mathrm{ppb}, 45.1 \mathrm{ppb}$ and $87.2 \mathrm{ppb}$ at GC, LTH and XL, respectively. The northern parts of China were dominated by a subtropical high in summer, located over the western Pacific, which led to weak winds and high temperature. Besides, higher ultraviolet radiation in north China (Hu et al., 2007) also is beneficial to the formation of ozone. However, the minimum concentrations which appeared in January of GC (6.9 ppb), December of LTH and XL (7.0 ppb and $23.4 \mathrm{ppb}$ ) differed in month. Generally speaking, $\mathrm{O}_{3}$ level in XL was significantly higher than that in other two sites during the observation periods, and there was a difference nearly $25 \mathrm{ppb}-30 \mathrm{ppb}$. This result was mainly due to a long range transport of air mass characterized by abundant precursors from the surrounding area (Tang et al., 2012). Similar result of higher ozone level in background region than that in urban area has also been found by Lin et al. (2008) at Shangdianzi (SDZ).

In the case of $\mathrm{NO}_{\mathrm{x}}$, it is the sum of $\mathrm{NO}_{2}$ and NO. NO is mainly produced by on-road motor vehicles and power plants. As Fig. 6b showed, $\mathrm{NO}_{\mathrm{x}}$ had apparently increasing trend from autumn to winter at GC and LTH, and the peak values in GC and LTH were $89.3 \mathrm{ppb}$ and $97.9 \mathrm{ppb}$, respectively. The concentration at XL did not show a sharply monthly variation like other sites. Moreover, similar variation patterns of $\mathrm{NO}_{2}$ and $\mathrm{NO}$ were also observed with maximum value in winter and minimum in summer. On one hand, this may be due to a stable thermal inversion layer which went against the diffusion of the $\mathrm{NO}_{\mathrm{x}}$. Also very few convective currents and small amount of precipitation made dry and wet deposition of $\mathrm{NO}_{\mathrm{x}}$ harder. On the other hand, $\mathrm{NO}_{\mathrm{x}}$ can be oxidized in the atmosphere to nitric acid and aerosol nitrates, but lower temperature and lower atmosphere oxidizing capacity did not favor gas-aerosol transformation. The concentration of $\mathrm{NO}_{\mathrm{x}}$ in $\mathrm{GC}$ was higher than that in LTH and XL during observation period, although NO in LTH was higher. The variations of NO showed a sharply increase and decrease trends at GC and LTH, respectively, in contrast with $\mathrm{NO}_{2}$. Statistics showed that the proportions of $\mathrm{NO}$ in $\mathrm{NO}_{\mathrm{x}}$ at GC, $\mathrm{LTH}$ and XL were 39.5\%, 49.3\% and 9.4\%, which meant that NO level significantly differed in regions of northern China. Consequently, NO is mainly produced by motor vehicle and its lifetime is short due to its reaction activity, and $\mathrm{NO}_{2}$ can produced by biomass burning besides automobile (Logan, 1983; Jacob et al., 1993). The air mass from the surrounding area can contribute to local $\mathrm{NO}_{2}$ concentrations, so the transport and local emission may be the reasons why $\mathrm{NO}_{2}$ concentration in GC rural site was higher than that in LTH urban site during August to January. NO concentration and proportion in XL site were extremely low and this meant that anthropogenic emission had a limited direct influence on the site.

$\mathrm{O}_{\mathrm{x}}$, defined as the sum of $\mathrm{NO}_{2}$ and $\mathrm{O}_{3}$, is a key indicator of the ability that atmosphere clear pollutants (Jenkin, 2004). 
Table 1

Statistic the annual average concentrations of air pollutants during observation period.

\begin{tabular}{|c|c|c|c|c|c|}
\hline & Site type & Observation period & $\begin{array}{l}\mathrm{O}_{3}(\text { Aver } \pm \mathrm{SD}) \\
(\mathrm{ppbv})\end{array}$ & $\begin{array}{l}\mathrm{NO}_{\mathrm{x}}(\text { Aver } \pm \mathrm{SD}) \\
(\mathrm{ppbv})\end{array}$ & $\begin{array}{l}\text { CO (Aver } \pm \text { SD) } \\
\text { (ppbv) }\end{array}$ \\
\hline GC & Rural & 2009.8.7-2010.6.8 & $19.4 \pm 7.9$ & $46.4 \pm 15.1$ & $1340 \pm 593$ \\
\hline LTH & Urban & 2009.8.7-2010.6.30 & $19.8 \pm 8.7$ & $53.4 \pm 29.7$ & $1432 \pm 675$ \\
\hline $\mathrm{XL}$ & Background & $2009.8 .8-2010.6 .8$ & $47.3 \pm 11.5$ & $9.2 \pm 4.8$ & $501 \pm 322$ \\
\hline
\end{tabular}

$\mathrm{O}_{\mathrm{x}}$ level showed a slight variation pattern compared with other trace gas at the three sites, and the maximum values at GC, LTH and XL were $63.6 \mathrm{ppb}, 70.3 \mathrm{ppb}$ and $96.4 \mathrm{ppb}$ in June, respectively. The intense $\mathrm{O}_{3}$ formation was due to the high temperature and strong UV-B radiation, which was the main reason of high $\mathrm{O}_{\mathrm{x}}$ concentration. As shown in Fig. 6e, $\mathrm{O}_{\mathrm{x}}$ concentration at XL was always higher than that at GC and LTH except for the period from October to February, which was mainly due to a massive emission of $\mathrm{NO}_{2}$ and a stable atmosphere in rural and urban areas, although $\mathrm{O}_{3}$ concentration at XL kept a high value during the observation period.
Fig. $6 \mathrm{f}$ showed that the variation pattern of $\mathrm{CO}$ was similar to $\mathrm{NO}_{\mathrm{x}}$ at GC and LTH with lower values in summer (736 ppb and $680 \mathrm{ppb}$ ) and higher values in winter (1990 ppb and $2880 \mathrm{ppb}$ ), which was mainly due to a large amount of fossil fuel combustion. However, the variation of CO in XL was complicated with its minimum value observed in March (310 ppb) and maximum value in August and September (590 ppb), which was mainly due to biomass burning in this harvest season. Generally speaking, CO is produced from three major sources: fossil fuel combustion, biomass burning and the oxidation of methane and non-methane hydrocarbons
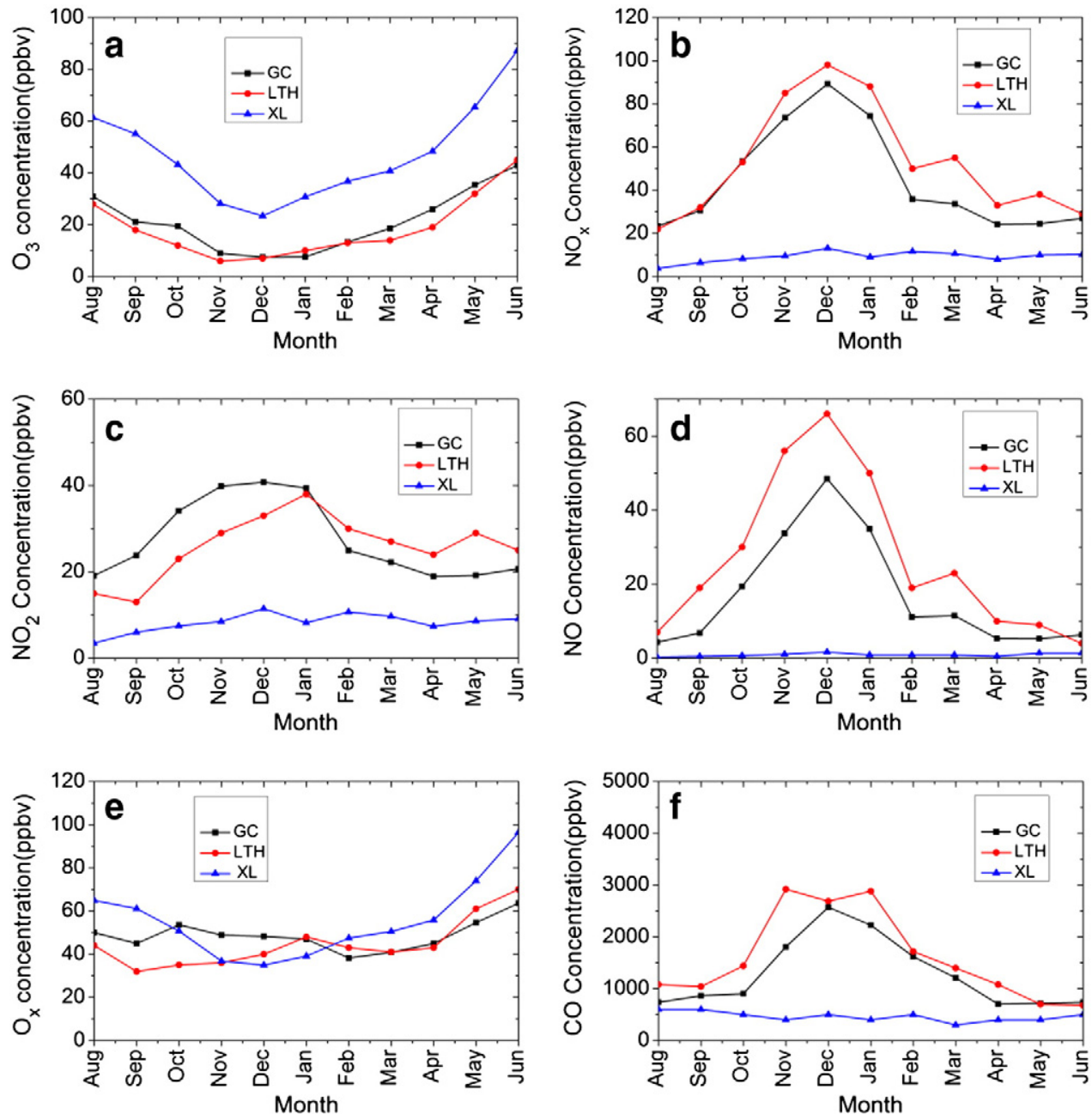

Fig. 6. Average monthly concentration of $\mathrm{O}_{3}, \mathrm{NO}_{\mathrm{x}}, \mathrm{NO}_{2}, \mathrm{NO}, \mathrm{O}_{\mathrm{x}}$ and $\mathrm{CO}$ at the three sites during the observation period. 

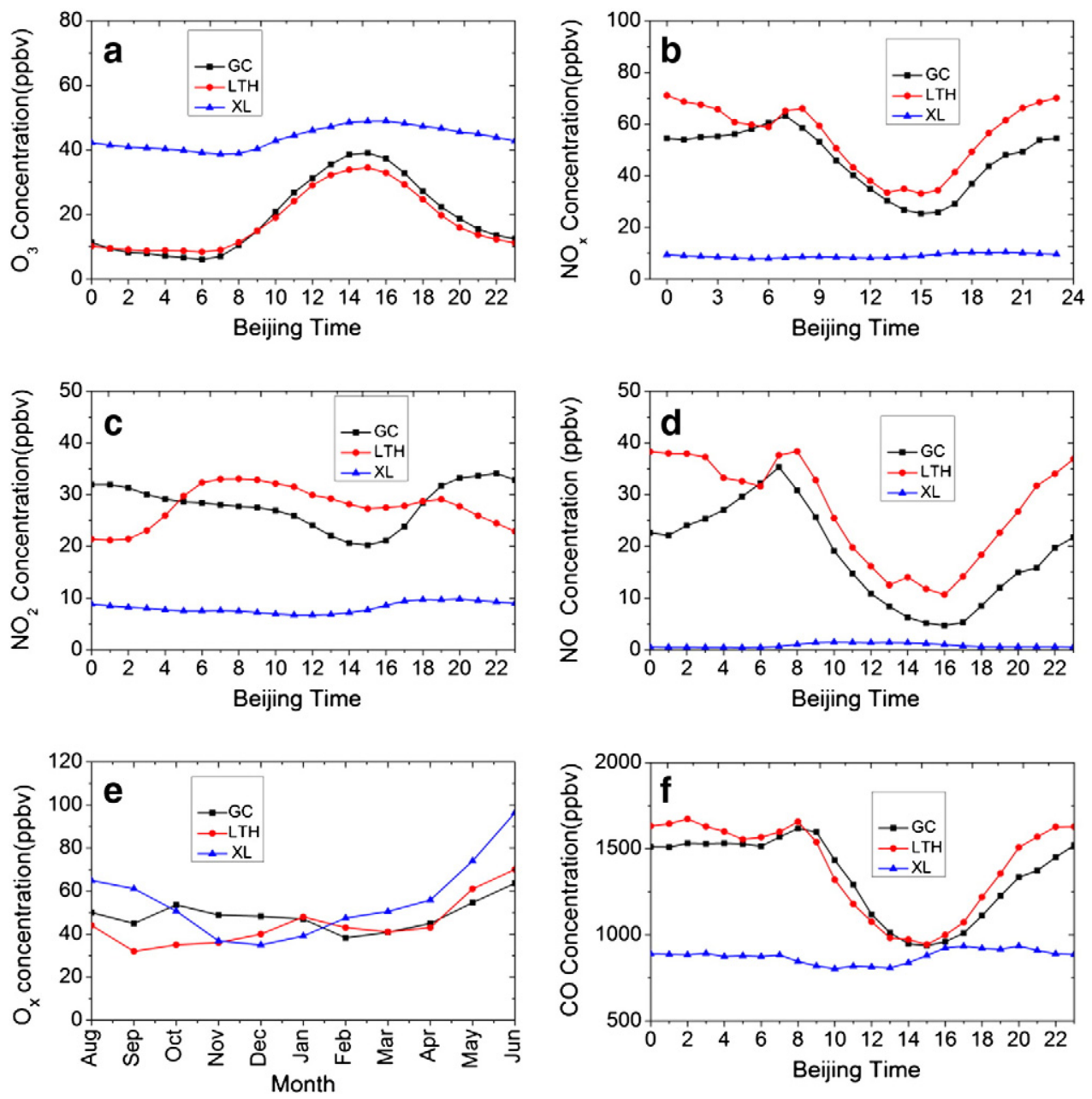

Fig. 7. Average hourly $\mathrm{O}_{3}, \mathrm{NO}_{\mathrm{x}}, \mathrm{NO}_{2}, \mathrm{NO}, \mathrm{O}_{\mathrm{x}}$ and $\mathrm{CO}$ variations at the three sites during the observation period.

(Novelli et al., 1992). As described in site location, the surroundings of three sites differ. The CO levels and variation patterns implied that fossil fuel consumption may contribute more in urban area than biomass burning and other oxidation products produced in the rural area.

\subsection{Diurnal variation}

The diurnal variation of air pollutants was pronouncedly influenced by the change of planetary boundary layer (PBL), solar radiation, wind circulation and emissions. Fig. 7 showed the diurnal variation of $\mathrm{O}_{3}, \mathrm{NO}_{\mathrm{x}}, \mathrm{NO}_{2}, \mathrm{NO}, \mathrm{O}_{\mathrm{x}}$ and $\mathrm{CO}$ at the three sites. The concentration of $\mathrm{O}_{3}$ (Fig. 7a) at GC and LTH exhibited clear peak values (39.1 ppb and $34.5 \mathrm{ppb}$ ) at nearly 15:00 LT (local time), while a slight variation pattern at XL was observed. The variation of $\mathrm{NO}_{\mathrm{x}}$ at GC and $\mathrm{LTH}$ showed opposite patterns compared with $\mathrm{O}_{3}$, together with valley values (28.8 ppb and 33.1 ppb) also at 15:00 LT. However, $\mathrm{NO}_{\mathrm{x}}$ concentration at XL varied from $7.9 \mathrm{ppb}$ to10.4 ppb and almost unchanged. This was mainly due to limited pollution sources around XL and air mass transported from upwind $\mathrm{NCP}$ was aged plume characterized by $\mathrm{NO}_{\mathrm{x}}$ and $\mathrm{CO}$ and other oxidation products. The $\mathrm{NO}_{2}$ concentration showed (Fig. 7c) two peak values at 9:00 LT (33.1 ppb) and 20:00 LT (29.1 ppb) at LTH and the two values were corresponding with the rush hours in Beijing. Conversely, $\mathrm{NO}_{2}$ variation showed lower concentration in daytime and higher concentration in night time, which was mainly due to the diurnal cycle of planetary boundary layer (PBL). Fig. $7 d$ showed that NO concentration exhibited opposite pattern to $\mathrm{O}_{3}$, as photochemical reaction and emission from vehicle distinctly impacted NO level. The maximum value in GC and LTH was $35.3 \mathrm{ppb}$ and $38.4 \mathrm{ppb}$ at 7:00 LT and 8:00 LT. NO concentration was always low in XL but high value was observed from 9:00 LT to 16:00 LT in XL, which was may be from the increase of anthropogenic emissions, for example, there will be more vehicles during this period of time than the other time.

The $\mathrm{O}_{\mathrm{x}}$ level at GC, $\mathrm{LTH}$ and XL showed peak values during the afternoon (Fig. 7e), and the maximum value appeared in $\mathrm{XL}$ at 17:00 LT due to the continuous transport accumulation of $\mathrm{O}_{3}$ from upwind region (Ma et al., 2011), although $\mathrm{NO}_{2}$ was almost stable. The amplitude in LTH was larger than other sites meant that the atmosphere oxidizing ability varied sharply.

The $\mathrm{CO}$ also exhibited peak values related to the accumulation of evening rush hours and biomass burning at LTH and GC, as Fig. 7f showed the early morning peak appeared at 8:00 
LT of GC (1618 ppb) and 2:00 LT of LTH (1690 ppb). This kind of variation pattern was also reported at other places (Gao et al., 2005). The peak value at XL appeared at 17:00 LT, which was mainly due to air mass from upwind area, such as Beijing and Tianjin. The oxidation of methane and non-methane hydrocarbons also contributed to $\mathrm{CO}$ concentration at XL due to high vegetation coverage. The lower $\mathrm{CO}$ concentration both at 15:00 LT of GC (938 ppb) and 15:00 LT of LTH (940 ppb) was caused by high $\mathrm{O}_{3}$ concentration, which can produce hydroxyl radical $(\mathrm{OH})$ through $(\mathrm{R} 1)$ and $(\mathrm{R} 2)$.

$\mathrm{O}_{3}+\mathrm{hv} \rightarrow \mathrm{O}\left({ }^{1} \mathrm{D}\right)$

$\mathrm{O}\left({ }^{1} \mathrm{D}\right)+\mathrm{H}_{2} \mathrm{O} \rightarrow 2 \mathrm{OH}$.

Then, $\mathrm{CO}$ was converted into $\mathrm{CO}_{2}$ (R3) by $\mathrm{OH}$. Therefore, hydroxyl radicals $(\mathrm{OH})$ were the major sink of $\mathrm{CO}$, especially at high $\mathrm{O}_{3}$ and intense ultraviolet radiation period (Pudasainee et al., 2006).

$\mathrm{CO}+\mathrm{OH} \rightarrow \mathrm{CO}_{2}+\mathrm{H}$.

Besides, the diurnal variation of air pollutants was affected by the daily behavior pattern of convective mixing layer, which was characterized by lower height during the night and before sunrise. The earth surface became cool faster than the air after sunset, therefore air temperature was higher than surface temperature, formatting a thermal structure inversion layer (Seinfeld and Pandis, 2006). $\mathrm{NO}_{\mathrm{x}}$ and $\mathrm{CO}$ would be accumulated due to weak convective activities. After sunrise, the earth surface became warmer faster than the air and the layer would be elevated and intensified the convective activities, thus, the diffusion of $\mathrm{NO}_{\mathrm{x}}$ and $\mathrm{CO}$ increased.
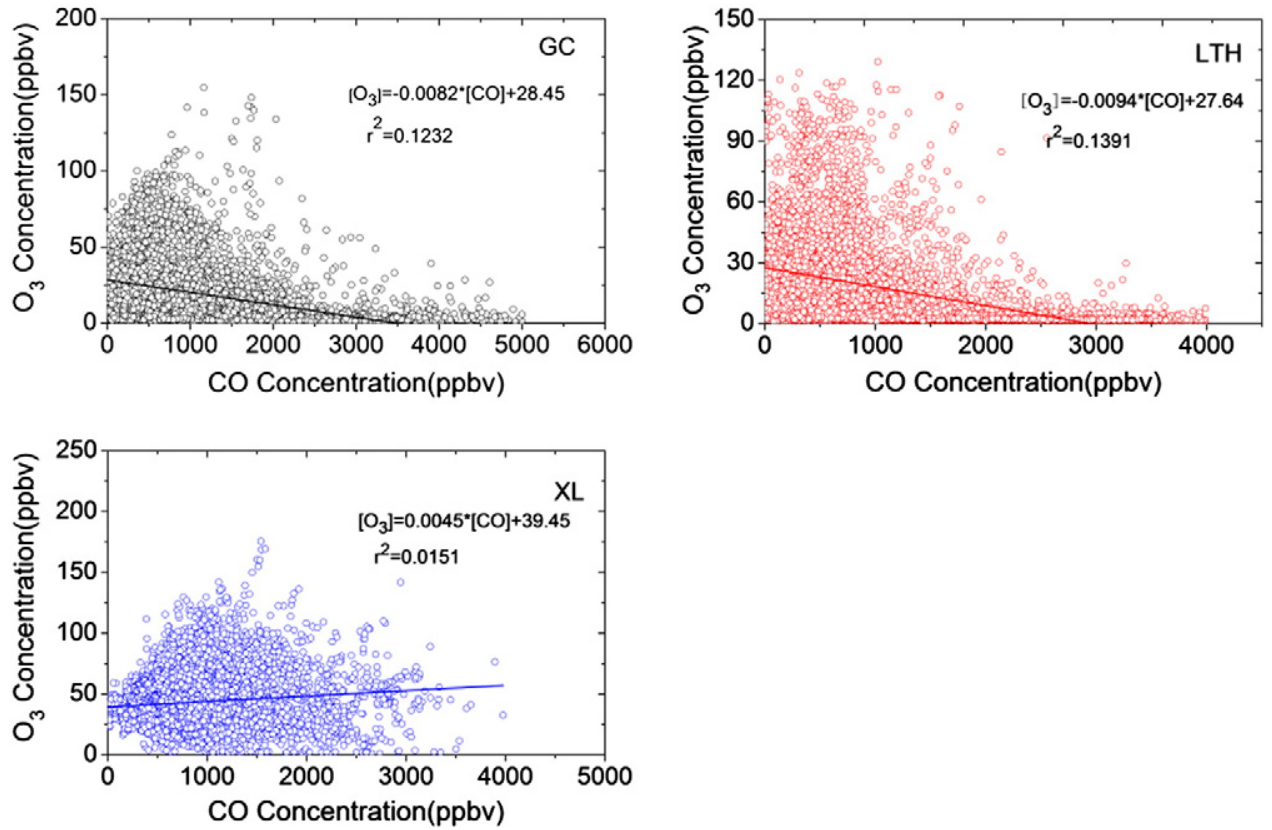

\subsection{Correlation between ozone and carbon monoxide}

CO is usually considered as an air pollution transport indicator owing to its lifetime of approximately one month. The atmospheric processes of air masses arriving at a monitoring site can be detected by examining the correlation between $\mathrm{O}_{3}$ and $\mathrm{CO}$. We analyzed the correlation of $\mathrm{O}_{3}$ and $\mathrm{CO}$ at the three sites in order to have an insight into the extent to which ozone was photochemically produced from primary pollutants that were co-emitted with CO. Fig. 8 illustrated scatter points of daily mean concentration of $\mathrm{O}_{3}$ and $\mathrm{CO}$ at GC, LTH and XL. Negative slopes both at GC $(-0.0082)$ and LTH $(-0.0094)$ indicated that the local emission of $\mathrm{CO}$ and other ozone precursors had significant influence on the formation of ozone. A positive slope (0.0045) in XL implied that air mass to XL had a large loading of anthropogenic emission experiencing strong photochemical processing. Similar correlations of $\mathrm{CO}$ and $\mathrm{O}_{3}$ have also been acquired in previous studies in north China and other urban area of the world (Wang et al., 2003, 2006, 2010; Teixeira et al., 2009; Xu et al., 2011a, 2011b, 2011c).

\subsection{Correlation between $\mathrm{NO}_{x}$ and $\mathrm{O}_{x}$}

The concentration of $\mathrm{O}_{\mathrm{x}}$ (defined as $\mathrm{O}_{3}+\mathrm{NO}_{2}$ ) can be described in terms of the sum of a $\mathrm{NO}_{x}$-independent 'regional' contribution (the background $\mathrm{O}_{3}$ ), and a linearly $\mathrm{NO}_{\mathrm{x}}$ dependent 'local' contribution. Fig. 9 showed the scatter plots of $\mathrm{NO}_{\mathrm{x}}$ versus $\mathrm{O}_{\mathrm{x}}$ concentration, along with plotted polynomial fit curves at the three sites. The slope obtained from the regression analysis represented the local $\mathrm{O}_{\mathrm{x}}$ contribution, while the intercept represents the $\mathrm{NO}_{\mathrm{x}}$-independent regional contribution. That is, the latter was equivalent to the background $\mathrm{O}_{3}$ concentration and the former was a local contribution that depended on the primary pollution. Local contribution to the formation of $\mathrm{O}_{3}$ was a linear function of the local emissions as

Fig. 8. Correlation between $\mathrm{O}_{3}$ and $\mathrm{CO}$ concentrations at the three sites during the observation period. 

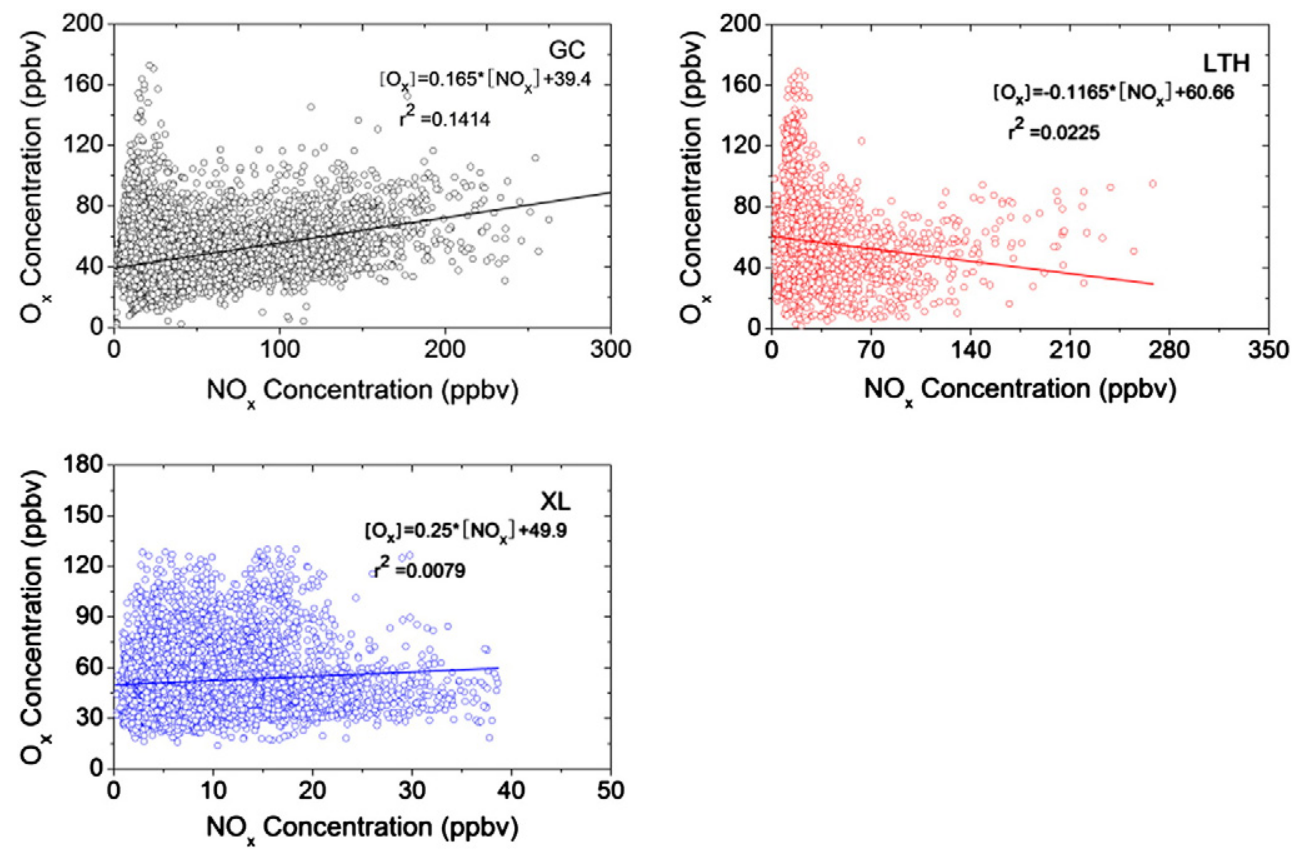

Fig. 9. Correlation between $\mathrm{NO}_{\mathrm{x}}$ and $\mathrm{O}_{3}$ concentrations at the three sites during the observation period.

can be seen in Fig. 9. The intercepts (background value) obtained from regression analysis data were $39.4 \mathrm{ppb}$ at GC, $60.7 \mathrm{ppb}$ at LTH and 49.9 at XL. It meant that atmospheric oxidizing ability varied a lot at north China, particular in different environment. Positive $\mathrm{NO}_{\mathrm{x}}-\mathrm{O}_{\mathrm{x}}$ correlation was observed at GC (0.165) and XL (0.25) site, while a negative correlation $(-0.1165)$ was observed in LTH. The similar negative values were also found by Jenkin (2004) at Derry, Coventry center and Manchester South. This was mainly due to a high level of NO concentration at urban area of Beijing, and titration reaction can reduce the formation of ozone at LTH. Furthermore, as we introduced in Section 2, the site is located in Longtanhu Park, which is almost in the center of Beijing. The surrounding was complex and emission sources were various. Thus, more filed observation with different sensors should be held in north China combined with model study to acquire a robust understanding of the ozone chemistry. In rural area and background area, positive correlation provided clear evidence that the local sources substantially contributed in the formation of ozone. Although the $\mathrm{NO}_{\mathrm{x}}$ level was lower in XL than GC, the slope was large. A possible reason for this was the contribution of biogenic hydrocarbon emissions in XL site. The surrounding of the site was covered with trees and shrubs, which can provide biogenic hydrocarbons (e.g. isoprene) to change the local $\mathrm{VOC} / \mathrm{NO}_{\mathrm{x}}$ ratio. In contrast, there was no significant biogenic source in the vicinity of GC site.

Furthermore, the ratio of $\mathrm{VOC} / \mathrm{NO}_{\mathrm{x}}$ should also be taken into account as a fundamental factor in analyzing ozone formation. Urban area is usually under a VOC regime, while rural and background areas are under $\mathrm{NO}_{\mathrm{x}}$ regime. So an increase of $\mathrm{NO}_{\mathrm{x}}$ in a certain range can resist the formation of ozone at LTH due to a $\mathrm{NO}_{\mathrm{x}}$-saturated condition (Seinfeld and Pandis, 2006).

\section{Conclusions}

Comparative study of $\mathrm{O}_{3}, \mathrm{NO}_{\mathrm{x}}\left(\mathrm{NO}_{\mathrm{x}}=\mathrm{NO}+\mathrm{NO}_{2}\right)$ and CO was conducted at GC, LTH and XL during August 2009 to June 2010, along with simultaneous metrological dates. The monthly variations of pollutants suggested that highest $\mathrm{O}_{3}$ concentrations were observed in summer due to increased photochemical activity. The ozone concentration was lower at LTH and GC compared with that at XL due to titration and $\mathrm{VOC} / \mathrm{NO}_{\mathrm{x}}$ ratio. The ozone concentration at $\mathrm{XL}$ site was significantly influenced by transportation of aged air mass from upwind area. The highest $\mathrm{NO}_{\mathrm{x}}$ and $\mathrm{CO}$ concentrations were observed in winter due to increasing pollutant emissions and adverse meteorological conditions, while the concentration of $\mathrm{O}_{\mathrm{x}}$ was higher at summer owing to a higher level of $\mathrm{O}_{3}$. Daily variations of pollutants indicated that $\mathrm{O}_{3}$ and $\mathrm{O}_{\mathrm{x}}$ had peak values at afternoon, while other primary pollutants had two peak values nearly at rush hours. Furthermore, higher concentrations of $\mathrm{O}_{3}$ and $\mathrm{O}_{\mathrm{x}}$ at background site XL also implied a robust atmospheric oxidizing ability. A positive correlation of $\mathrm{CO}$ to $\mathrm{O}_{3}$ at XL site implied that air mass to the site had a large loading of anthropogenic emission experiencing strong photochemical processing, while negative slopes both at GC and LTH indicated that local emission of precursors had significant influence on the formation of ozone. Positive correlations of $\mathrm{NO}_{\mathrm{x}}$ to $\mathrm{O}_{\mathrm{x}}$ in $\mathrm{GC}$ and $\mathrm{XL}$ implied that $\mathrm{NO}_{\mathrm{x}}$ contributes to the formation of ozone, while a negative correlation meant titration in urban site LTH neutralized the formation of ozone due to high level of NO. Ozone pollution in NCP region was complex and our understanding was limited, so more observation should be carried out combined with numerical simulations. 


\section{Acknowledgments}

We acknowledge Professor Lin Weili at Chinese Academy of Meteorological Sciences for data quality control of GC site. This work was supported by the National Natural Science Foundation of China (41230642) and the CAS Strategic Priority Research Program Grant No. XDA05100100. This work was also supported by China Special Fund for Meteorological Research in the Public Interest (GYHY201206015). The authors would like to thank the staff at the three sites for the instrument maintenance.

\section{References}

Chan, C., Yao, X., 2008. Air pollution in mega cities in China. Atmos. Environ. $42,1-42$.

Chelani, A., 2009. Statistical persistence analysis of hourly ground level ozone concentrations in Delhi. Atmos. Res. 92, 244-250.

Chu, D.A., Kaufman, Y.J., Zibordi, G., Chern, J.D., Mao, J.T., Li, C.C., Holben, B.N., 2003. Global monitoring of air pollution over land from the Earth Observing System-Terra Moderate Resolution Imaging Spectroradiometer (MODIS). J. Geophys. Res. 108, 4661.

Duan, J., Tan, J., Yang, L., Wu, S., Hao, J., 2008. Concentration, sources and ozone formation potential of volatile organic compounds (VOCs) during ozone episode in Beijing. Atmos. Res. 88, 25-35.

Gao, J., Wang, T., Ding, A.J., Liu, C.B., 2005. Observational study of ozone and carbon monoxide at the summit of mount Tai (1534 $\mathrm{m}$ a.s.l.) in centraleastern China. Atmos. Environ. 39, 4779-4791.

Grewe, V., Dahlmann, K., Matthes, S., Steinbrecht, W., 2012. Attributing ozone to $\mathrm{NO}_{\mathrm{x}}$ emissions: implications for climate mitigation measures. Atmos. Environ. 59, 102-107.

Hu, B., Wang, Y.S., Liu, G.R., 2007. Ultraviolet radiation spatial-temporal characteristics derived from ground-based measurements taken in China. Atmos. Environ. 41, 5707-5718.

Jacob, D.J., Logan, J.A., Gardner, G.M., Yevich, R.M., Spivakovsky, C.M., Worfsy, F.C., Sillman, S., Prather, M.J., 1993. Factors regulating ozone over the United States and its export to the global atmosphere. J. Geophys. Res. 14, 817-826.

Jenkin, M.E., 2004. Analysis of sources and partitioning of oxidant in the UK - part 1: the $\mathrm{NO}_{\mathrm{x}}$-dependence of annual mean concentration of nitrogen dioxide and ozone. Atmos. Environ. 38, 5117-5129.

Li, Q.B., Jacob, D.J., Bey, I., Palmer, P., Duncan, B.N., Field, B.D., Martin, R.V., Fiore, A.M., Yantosca, R.M., Parrish, D.D., Simmonds, P.G., Oltmans, S.J., 2002. Transatlantic transport of pollution and its effects on the surface ozone in Europe and North America. J. Geophys. Res. 107. http:// dx.doi.org/10.1029/2001JD001422.

Lin, W.L., Xu, X.B., Zhang, X.C., Tang, J., 2008. Contributions of pollutants from North China Plain to surface ozone at the Shangdianzi GAW Station. Atmos. Chem. Phys. 8, 5889-5898.

Lin, W.L., Xu, X.B., Ge, B.Z., Zhang, X.C., 2009. Characteristics of gaseous pollutants at Gucheng, a rural site southwest of Beijing. J. Geophys. Res. 114, D00G14. http://dx.doi.org/10.1029/2008JD010339.

Lin, W.L., Xu, X.B., Ge, B.Z., Liu, X., 2011. Gaseous pollutants in the Beijing urban area during the heating period 2007-2008: variability, sources, meteorological, and chemical impacts. Atmos. Chem. Phys. 11, 8157-8170.

Logan, J.A., 1983. Nitrogen oxides in the troposphere: global and regional budgets. J. Geophys. Res. 88, 10785-10807.

Ma, Z.Q., Wang, Y.S., Zhang, X.L., Xu, J., 2011. Comparison of ozone between Beijing and downstream area. Environ. Sci. 4 (32), 924-929 (in Chinese with English abstract).

Mao, B.H., 2008. Analysis on transport policies of post-Olympic times of Beijing. J. Transp. Syst. Eng. Inf. Technol. 8 (6), 138-145.

Mazzeo, N.A., Venegas, L.E., Choren, H., 2005. Analysis of $\mathrm{NO}, \mathrm{NO}_{2}, \mathrm{O}_{3}$ and $\mathrm{NO}_{\mathrm{x}}$ concentration measured at a green area of Buenos Aires City during wintertime. Atmos. Environ. 39, 3055-3068.
Mckenzie, R., Connor, B., Bodeker, G., 1999. Increased summertime UV radiation in New Zealand in response to ozone loss. Science 285, 1709-1711.

Minoura, H., 1999. Some characteristics of surface ozone concentration observed in an urban atmosphere. Atmos. Res. 51, 153-169.

Novelli, P.C., Steele, L.P., Tans, P.P., 1992. Mixing ratios of carbon monoxide in the troposphere. J. Geophys. Res. 97, 731-750.

Pudasainee, D., Sapkota, B., Shrestha, M.L., Kaga, A., Kondo, A., Inoue, Y., 2006. Ground level ozone concentration and its association with $\mathrm{NO}_{\mathrm{x}}$ and meteorological parameters in Kathmandu valley, Nepal. Atmos. Environ. 40, 8081-8087.

Seinfeld, J.H., Pandis, S.N., 2006. Atmospheric Chemistry and Physics: From Air Pollution to Climate Change. ed John Wiley \& Sons, New York.

Shan, W., Yin, Y., Zhang, J., Ding, Y., 2008. Observation study of surface ozone at an urban site in East China. Atmos. Res. 89, 252-261.

Shan, W., Yin, Y., Lu, H., Liang, S., 2009. A meteorological analysis of ozone episodes using HYSPLIT model and surface data. Atmos. Res. 93, 767-776.

Shan, W., Zhang, J., Huang, Z., You, L., 2010. Characterization of ozone and related compounds under the influence of maritime and continental winds at a coastal site in the Yangtze Delta, nearby Shanghai. Atmos. Res. 97, 26-34.

Singla, V., Satsangi, A., Pachauri, T., Lakhani, A., Kumari, K., 2011. Ozone formation and destruction at a sub-urban site in North Central region of India. Atmos. Res. 101, 373-385.

Streets, D.G., Fu, J.S., Jang, C.J., Hao, J.M., He, K.B., Tang, X.Y., Zhang, Y.H., Wang, Z.F., Li, Z.P., Zhang, Q., Wang, L.T., Wang, B.Y., Yu, C., 2007. Air quality during the 2008 Beijing Olympic Games. Atmos. Environ. 41, 480-492.

Sun, Y., Wang, L.L., Wang, Y.S., Zhang, D.Q., Liu, Q., Xin, J.Y., 2010. In situ measurements of $\mathrm{NO}, \mathrm{NO}_{2}$, and $\mathrm{O}_{3}$ in Dinghushan $\left(112^{\mathrm{O}} \mathrm{E}, 23^{\mathrm{O}} \mathrm{N}\right)$, China during autumn 2008. Atmos. Environ. 44, 2079-2088.

Tang, G., Li, X., Wang, Y., Xin, J., Ren, X., 2009. Surface ozone trend details and interpretations in Beijing, 2001-2006. Atmos. Chem. Phys. 9, 8813-8823.

Tang, G., Wang, Y., Li, X., Ji, D., Hsu, S., Gao, X., 2012. Spatial-temporal variations in the surface ozone in the Northern China as observed during 2009-2010 and possible implications for future air quality control strategies. Atmos. Chem. Phys. 12, 2757-2776.

Teixeira, E.C., Santana, E.R.D., Wiegand, F., Fachel, J., 2009. Measurement of surface ozone and its precursors in an urban area in South Brazil. Atmos. Environ. 43, 2213-2220.

Tu, J., Xia, Z., Wang, H., Li, W., 2007. Temporal variations in surface ozone and its precursors and meteorological effects at an urban site in China. Atmos. Res. 85, 310-337.

Wang, T., Ding, A.J., Blake, D.R., Zahorowski, W., Poon, C.N., Li, Y.S., 2003. Chemical characterization of the boundary layer outflow of air pollution to Hong Kong during February-April 2001. J. Geophys. Res. 108 (D20), 8787.

Wang, T., Ding, A.J., Gao, J., Wu, W.S., 2006. Strong ozone production in urban plumes from Beijing, China. Geophys. Res. Lett. 33, L21806.

Wang, T., Nie, W., Gao, J., Xue, L.K., Gao, X.M., Wang, X.F., Qiu, J., Poon, C.N., Meinardi, S., Blake, D., Wang, S.L., Ding, A.J., Chai, F.H., Zhang, Q.Z., Wang, W.X., 2010. Air quality during the 2008 Beijing Olympics: secondary pollutants and regional impact. Atmos. Chem. Phys. 10, 7603-7615.

Xin, J.Y., Wang, Y.S., Tang, G.Q., Wang, L.L., Sun, Y., Wang, Y.H., Hu, B., Song, T., Ji, D.S., Wang, W.L., Li, L., Liu, G.R., 2010. Variability and reduction of atmospheric pollutants in Beijing and its surrounding area during the Beijing 2008 Olympic Games. Chin. Sci. Bull. 55, 1510-1519.

Xu, J., Zhang, X.L., Xu, X.F., Zhao, X.J., Meng, W., Pu, W.W., 2011a. Measurement of surface ozone and its precursors in urban and rural sites in Beijing. Procedia Earth Planet. Sci. 2, 255-265.

Xu, J., Ma, J.Z., Zhang, X.L., Xu, X.B., Xu, X.F., Lin, W.L., Wang, Y., Meng, W., Ma, Z.Q., 2011b. Measurement of ozone and its precursors in Beijing during summertime: impact of urban plumes on ozone pollution in downwind rural areas. Atmos. Chem. Phys. 11, 12241-12252.

Xu, W.Y., Zhao, C.S., Ran, L., Deng, Z.Z., Liu, P.F., Ma, N., Lin, W.L., Xu, X.B., Yan, P., He, X., Yu, J., Liang, W.D., Chen, L.L., 2011c. Characteristics of pollutants and their correlation to meteorological conditions at a suburban site in the North China Plain. Atmos. Chem. Phys. 11, 4353-4369. 